\title{
Effect of different concentrations of municipal solid waste on metal uptake of wheat (Triticum aestivum)
}

\author{
Ifra Saleem Malik ${ }^{1}$, Zafar Iqbal Khan ${ }^{1 *}$, Kafeel Ahmad ${ }^{1}$, Kinza \\ Wajid $^{1}$, Mubeen Akhtar ${ }^{1}$, Maria Ghazzal ${ }^{1}$, Khalid Nawaz ${ }^{2}$, Humayun \\ Bashir $^{1}$, Mudasra Munir ${ }^{1}$, Asma Ashfaq ${ }^{1}$, Muhammad Nadeem ${ }^{3}$, \\ Naunain Mehmood ${ }^{4}$, Pervaiz Akhter ${ }^{1}$, Zarin Fatima ${ }^{5}$, Saif Ullah ${ }^{6}$, Hira \\ Muqaddas $^{7}$, Mahpara Shehzadi ${ }^{8}$, Ijaz Rasool Noorka ${ }^{9}$
}

1. Department of Botany, University of Sargodha, Sargodha-Pakistan

2. Department of Botany, University of Gujrat, Gujrat-Pakistan

3. Institute of Food Science and Nutrition, University of Sargodha, Sargodha-Pakistan

4. Department of Zoology, University of Sargodha-Pakistan

5. Department of Botany, Government College for Women University, Sialkot-Pakistan

6. Department of Economics, University of Sargodha-Pakistan

7. Department of Zoology, Women University, Multan-Pakistan

8. Department of Plant Breeding \& Genetics, Faculty of Agricultural Sciences, Ghazi University, Dera Ghazi Khan-Pakistan

9. Department of Plant Breeding \& Genetics, Faculty of Agriculture, University of Sargodha, Sargodha-Pakistan *Corresponding author's email: zafar.khan@uos.edu.pk

\section{Citation}

Ifra Saleem Malik, Zafar Iqbal Khan, Kafeel Ahmad, Kinza Wajid, Mubeen Akhtar, Maria Ghazzal, Khalid Nawaz, Humayun Bashir, Mudasra Munir, Asma Ashfaq, Muhammad Nadeem, Naunain Mehmood, Pervez Akhtar, Zarin Fatima, Saif Ullah, Hira Muqaddas, Mahpara Shehzadi, Ijaz Rasool Noorka. Effect of different concentrations of municipal solid waste on metal uptake of wheat (Triticum aestivum). Pure and Applied Biology. Vol. 8, Issue 4, pp2193-2203. http://dx.doi.org/10.19045/bspab.2019.80165

\begin{tabular}{llll}
\hline \hline Received: 15/05/2019 & Revised: 10/07/2019 & Accepted: 17/07/2019 & Online First: 23/07/2019 \\
\hline \hline
\end{tabular}

\section{Abstract}

Heavy metal accumulation in edible parts of plants is major international concern now a day. This research was aimed to observe the influence of different level of municipal solid waste on metal accumulation by wheat variety (Inqalab-91). The metal concentration in soil and wheat grains was quantified using atomic absorption spectrophotometer (AA-6300 Shimadzu Japan). Results demonstrated that municipal solid waste treatment increased the heavy metals in various parts (root, shoot, grains) of wheat plant. The metals in wheat grains varied from 1.5-2.46, 10-18.16, 0.8-0.95 and $0.53-0.95 \mathrm{mg} / \mathrm{kg}$ for $\mathrm{Cd}, \mathrm{Fe}, \mathrm{Zn}$ and Co, respectively. The amount of all heavy metals were determined within the permissible range except for $\mathrm{Cd}$. The cadmium had the highest bio concentration and enrichment factor. The pollution load index values for $\mathrm{Cd}$ and $\mathrm{Co}$ were the highest. The health risk index values for $\mathrm{Cd}, \mathrm{Fe}$ and $\mathrm{Co}$ were $>1$ indicating that wheat grains were not suitable for human consumption. So, it is concluded that proper treatment of municipal solid waste is necessary before its application on land.

Keywords: Heavy metal; Municipal solid waste; Triticum aestivum

\section{Introduction}

The competition for development among different nation of the world purported very effects to human life. Every country is dependent on agricultural and industrial progress for its development to attain the goals of progress every country has to make use of all its available resources [1].

Cereal are the most important portion of the food for human as well as for animals now 
a days they are playing very important role as energy production such as biogas and bioethanol which are produced from the fermentation are chiefly produced by cereals crops. Different varieties of wheat exist worldwide, the most important type which is being cultivated (Triticum aestivum) and hard wheat (Triticum durum). Triticum aestivum as compared to the hard wheat is rich in phosphorus, starch, iron, vitamin B and fats and can be easily grown in temperate and hot areas [2].

The element of high density (usually < $5 \mathrm{~g} / \mathrm{cm}^{3}$ ) are termed as the heavy metals and even the little amount can be very toxic. These elements exist naturally in soil high $\mathrm{pH}$ induces their mobility [3] amongst the dangerous element which can cause very serious effects to livings are arsenic, chromium, lead, nickel, cadmium, mercury, beryllium, selenium and manganese [4].

Heavy metals bring along them very negative effects to the environment because of their half-life and non-biodegradable nature [5]. Owing to the exorbitant concentration of copper in cereal causes liver damage and failure of hair pigmentation [6]. High level of $\mathrm{Zn}$ takes part in weakness of muscles, nausea and pain. Higher doses of such metals in the wheat can lead to serious health problems [7].

Industrial wastes are the chief source of the heavy metals, as they pour their all waste material in running water, lakes and stream and accelerate their amount in the water. This untreated water in many countries, used for agriculture purposes [8, 9], it brings very harmful effects on crops and soil. This high concentration of the heavy metals which are present in crops causes very lethal effects to the heath of human and animals through the food chain [10].

The current work was performed with objectives: (1) to examine the metal concentration in different parts of wheat plant, (2) to determine bioconcentration factor and transfer factor, (3) to estimate pollution load index, (4) to appraise health risk index.

\section{Materials and methods Study area}

In order to analyse heavy metal content in the wheat (Triticum aestivum L.) using municipal solid waste treatment, a pot experiment was conducted at Department of Botany, University of Sargodha during 2016-2017.

\section{Plant cultivation}

Twelve pots were filled with $3 \mathrm{~kg}$ soil. After that, wheat variety (Inqalab-91) was grown in four groups, one control group (ground soil) and the remaining three treatments with various amount of municipal solid waste. Eight seeds were sown in each pot. T1 consisted of $100 \%$ ground soil. T2 consisted of $25 \%$ municipal solid waste and $75 \%$ ground soil. T3 consisted of $50 \%$ municipal solid waste and $50 \%$ ground soil. T4 consisted of $75 \%$ municipal solid waste $25 \%$ ground soil. Three replicates of the selected crop were made for each treatment. Plants were irrigated twice a weak. Maturation period was 5 months. Different morphological parameters of different varieties of wheat were also observed. Plants were harvested in April, 2017.

\section{Sample preparation}

After harvesting plants were oven dried. After removing from the oven, grains were separated from the spikes and ground in electrical grinder into fine powder, for heavy metal detection $1 \mathrm{~g}$ of each sample was taken and digested as wet digestion method.

\section{Wet digestion of grains and soil}

The dried samples were placed in a small conical flask and digested with conc. $\mathrm{HNO}_{3}$ and $\mathrm{H}_{2} \mathrm{O}_{2}$ 1:2 on a hot plate. When fumes disappear, samples were removed from the heat and $\mathrm{H}_{2} \mathrm{O}_{2}$ was further added to attain transparent solution and again placed on the hot plate. Digestion continued until colourless solution appeared. After cooling, samples were diluted with distilled water up to $50 \mathrm{~mL}$ and filtered through Whatman filter paper No. 42.

The soil samples were collected from the upper 3-5 cm layer of the soil from each pot. After drying in the oven, the samples 
were digested in the same manner. The ground and sewage water also digested.

\section{Metals concentration}

All the digested samples were then subjected to atomic absorption spectrophotometer (AA-6300 Shimadzu Japan) to detect heavy metals in them. The metals to be analysed were cobalt $(\mathrm{Co})$, zinc $(\mathrm{Zn})$, iron $(\mathrm{Fe})$ and cadmium $(\mathrm{Cd})$. For detection, the standard solution of different metals was also prepared from the stock solution, to obtain a calibration curve.

\section{Quality control}

To assess the reliability and assurance of the data, such measures were taken. By comparing with the international standards, the precision of the results can be done. The repeated analyses of the examined samples can also verify the accuracy of the analyses.

\section{Statistical analysis}

The results were subjected to analysis of variance (ANOVA) and the correlation using SPSS (Statistical Package for Social Sciences) software, Version 16.0 [11].

Bioconcentration factor and health risk index was determined by following Cui et al. [12]. Pollution load index was calculated by method described by Liu et al. [13]. Daily intake of metal was according to Sajjad et al. [14]. Al-Hwaiti and AlKhashman [15] was followed for calculation of enrichment factor.

\section{Results}

\section{Morphological parameters}

Results showed that municipal solid waste significantly affected the morphological parameters of wheat (Table 1). The following order for effect of different treatments on morphological parameters was observed: T4>T3>T2>T1. The maximum values of morphological parameters were seen at T4 (Table 2).

\section{Cadmium contents in soil and grain}

The results from ANOVA depicted that treatments have non-significant effect $(p>0.05)$ on concentration of $\mathrm{Cd}$ in soil (Table 3). Cd content in all treatments was found in following sequence: T1 $>$ T2>T4>T3 (Table 4). Non-significant effect $(p>0.05)$ of treatments was observed in $\mathrm{Cd}$ content in grains (Table 3 ). The $\mathrm{Cd}$ content in grain of wheat variety (Inqalab91) was in found in following order $\mathrm{T} 2>\mathrm{T} 4>\mathrm{T} 1>\mathrm{T} 3$. The comparison between four different treatments indicated that $\mathrm{Cd}$ was the highest in $\mathrm{T} 2$ while the least concentration of Cd was found in T1 (Table 4).

\section{Iron contents in soil and grain}

The results from ANOVA depicted that treatments have non-significant impact ( $>0.05$ ) on level of $\mathrm{Fe}$ in soil (Table 3). Order that found in the soil of $\mathrm{Fe}$ was $\mathrm{T} 4>\mathrm{T} 2>\mathrm{T} 3>\mathrm{T} 1$ in wheat variety Inqalab91. Fe was the highest in T4 while the least concentration of Fe was found in T1. In the soil, Fe content ranges from 31.7 to 41.3 $\mathrm{mg} / \mathrm{kg}$ (Table 4).

The treatments show non-significant effect (p>0.05) on Fe content in soil (Table 3). Fe content in grain of wheat variety (Inqalab91) was in found in following order $\mathrm{T} 2>\mathrm{T} 3>\mathrm{T} 4>\mathrm{T} 1$. Fe was the highest in T2 while the least concentration of $\mathrm{Fe}$ was found in $\mathrm{T} 1$. The Fe content in grains of wheat in present study ranges from 10 to $18.16 \mathrm{mg} / \mathrm{kg}$ (Table 4).

\section{Zinc contents in soil and grain}

The ANOVA depicted treatments show non-significant effect $(p>0.05)$ on $\mathrm{Zn}$ content in soil (Table 3). The level of $\mathrm{Zn}$ in soil was found in following sequence: T2>T3>T4> T1. Zn content was the highest in $\mathrm{T} 2$ while the least concentration of was found in T1. In soil, the concentration of $\mathrm{Zn}$ ranges from 2.16 to $2.28 \mathrm{mg} / \mathrm{kg}$ (Table 4 ). The treatments result non-significant effect $(p>0.05)$ on $\mathrm{Zn}$ content in the grains (Table $3)$. The mean concentration of $\mathrm{Zn}$ in grains was found in following order $\mathrm{T} 4>\mathrm{T} 3>\mathrm{T} 1>\mathrm{T} 2$. Zn content was highest in $\mathrm{T} 4$ while the least concentration of $\mathrm{Zn}$ was found in $\mathrm{T} 2 . \mathrm{Zn}$ in grains of wheat ranges $0.80-0.95 \mathrm{mg} / \mathrm{kg}$ (Table 4).

\section{Cobalt contents in soil and grain}

The treatments demonstrated nonsignificant impact $(\mathrm{p}>0.05)$ on Co content in soil and grains (Table 3 ). The Co content 
in the soil was in following order T4>T3>T2>T1. Co content was highest in $\mathrm{T} 4$ while the least concentration of Co was found in T1. In soil, values of Co ranged from 1.15 to $1.73 \mathrm{mg} / \mathrm{kg}$ (Table 4). The mean concentration of $\mathrm{Co}$ in the grains of wheat variety (Inqalab-91) was in following order T2>T4>T3>T1. In T2, Co mean concentration was highest while the least concentration of Co was found in $\mathrm{T} 1$. The Co content in grains of wheat variety ranged from 0.5 to $0.95 \mathrm{mg} / \mathrm{kg}$ (Table 4).

\section{Bioconcentration factor of wheat}

Transfer factor at T1, T2, T3 and T4 was in following trend respectively: $\mathrm{Fe}>\mathrm{Co}>\mathrm{Cd}>\mathrm{Zn}, \quad \mathrm{Cd}>\mathrm{Fe}>\mathrm{Co}>\mathrm{Zn}$, $\mathrm{Fe}>\mathrm{Cd}>\mathrm{Co}>\mathrm{Zn}$ and $\mathrm{Cd}>\mathrm{Fe}>\mathrm{Zn}>\mathrm{Co}$ (Table 5).

\section{Pollution load index of wheat}

The sequence of PLI at T1, T2, T3 and T4 was: $\mathrm{Cd}>\mathrm{Fe}>\mathrm{Co}>\mathrm{Zn}$. The PLI of $\mathrm{Cd}$ was highest while $\mathrm{Co}$ and $\mathrm{Zn}$ was lowest at four treatments. In current study, PLI for Cd was greater than 1 and $\mathrm{Fe}, \mathrm{Co}$ and $\mathrm{Zn}$ remained lower than 1. High pollution load index was observed for $\mathrm{Cd}$ due to high percentage of sewage sludge (Table 5).

\section{Enrichment factor for wheat}

The order of enrichment factor was $\mathrm{Cd}>\mathrm{Zn}>\mathrm{Co}>\mathrm{Fe}$ in $\mathrm{T} 1, \mathrm{~T} 2$ and $\mathrm{T} 3$ and differ for $\mathrm{T} 4$ that was $\mathrm{Cd}>\mathrm{Zn}>\mathrm{Fe}>\mathrm{Co}$. When enrichment value is high $(>1)$ it indicates higher availability and distribution of metals (Table 5).

\section{Transfer factor (root-shoot) of wheat}

In all treatments, Co showed the highest values for $\mathrm{TF}$ and it was lowest for $\mathrm{Cd}$. The orders of TF for T1, T2, T3 and T4 were $\mathrm{Co}>\mathrm{Cd}>\mathrm{Zn}>\mathrm{Fe}$, $\mathrm{Co}>\mathrm{Fe}>\mathrm{Cd}>\mathrm{Zn}$, $\mathrm{Cd}>\mathrm{Co}>\mathrm{Zn}>\mathrm{Fe}$ and $\mathrm{Co}>\mathrm{Fe}>\mathrm{Zn}>\mathrm{Cd}$, respectively (Table 6).

\section{Transfer factor (shoot-grain) of wheat} In four treatments, $\mathrm{Cd}$ exhibited the highest values for TF and it was the lowest for Co. The trend of $\mathrm{TF}$ for $\mathrm{T} 1, \mathrm{~T} 2, \mathrm{~T} 3$ and $\mathrm{T} 4$ were $\mathrm{Cd}>\mathrm{Co}>\mathrm{Zn}>\mathrm{Fe}$,

$\mathrm{Co}>\mathrm{Cd}>\mathrm{Fe}>\mathrm{Zn}$,
$\mathrm{Co}>\mathrm{Fe}>\mathrm{Cd}>\mathrm{Zn}$ and $\mathrm{Cd}>\mathrm{Zn}>\mathrm{Co}>\mathrm{Fe}$, correspondingly (Table 6).

\section{Daily intake of metal in wheat}

Among four treatments, daily intake of metals for Co was higher in T2, T3 and T4 while lower for $\mathrm{Cd}$ and $\mathrm{Zn}$. The order of daily intake of metals for T3 and T4 were same as $\mathrm{Co}>\mathrm{Fe}>\mathrm{Cd}>\mathrm{Zn}$ but differed for $\mathrm{T} 1$ : $\mathrm{Co}>\mathrm{Fe}>\mathrm{Zn}>\mathrm{Cd}$ and $\mathrm{T} 2: \mathrm{Co}>\mathrm{Cd}>\mathrm{Fe}>\mathrm{Zn}$ (Table 7).

\section{Health risk index of wheat}

The trend of $\mathrm{HRI} \mathrm{Cd}>\mathrm{Co}>\mathrm{Fe}>\mathrm{Zn}$ was same for T1, T2, T3 and T4 respectively. If HRI for food crop is <1, only then it is considered safe for consumers' health, however if HRI $>1$ it exerts hazardous effects on human health (Table 7).

\section{Correlation of wheat}

In present findings, $\mathrm{Fe}$ and $\mathrm{Cd}$ exhibited positive and non-significant $(p>0.05)$ correlation among root and soil of wheat variety (Inqalab-91). Co showed positive and highly significant correlation. $\mathrm{Cd}$ and $\mathrm{Fe}$ showed slightly strong relationship between soil and root and $\mathrm{Zn}$ had a positive and significant correlation, whereas, Fe and Co showed positive and significant correlation from root to shoot while positive and non-significant correlation was estimated for $\mathrm{Zn}$ and $\mathrm{Co}$.

In the present investigation, the $\mathrm{Cd}, \mathrm{Fe}$ and $\mathrm{Zn}$ showed positive and non-significant correlation and the Co showed negative and non-significant correlation (Table 8).

\section{Discussion}

The mean level of $\mathrm{Cd}$ in soil ranged from 2.80 to $2.98 \mathrm{mg} / \mathrm{kg}$. The value of $\mathrm{Cd}$ was similar to present value that is $2.80 \mathrm{mg} / \mathrm{kg}$ given by Hassan et al. [16]. The value of $\mathrm{Cd}$ was lower that was $0.20 \mathrm{mg} / \mathrm{kg}$ given by Rattan et al. [17] as compared to the value found in present study. Geochemically $\mathrm{Cd}$ is relatively movable element in soil and it is easily taken up by plants. Due to high toxicity $\mathrm{Cd}$ has a bad repute and unapproachable to growth of plants [18]. 
Table 1. Analysis of variance for morphological parameters of wheat

\begin{tabular}{|c|c|c|c|c|c|c|}
\hline SOV & DF & \multicolumn{5}{|c|}{ Mean squares } \\
\hline & & Leaf length & Leaf width & Leaf area & Root length & Shoot length \\
\hline Treatments & 3 & $35.460^{\mathrm{ns}}$ & $.103^{\mathrm{ns}}$ & $52.881^{\mathrm{ns}}$ & $20.460^{\mathrm{ns}}$ & $19.548^{\mathrm{ns}}$ \\
\hline Error & 8 & 18.258 & .019 & 13.165 & 13.516 & 41.051 \\
\hline
\end{tabular}

ns: non-significant

Table 2. Morphological parameters of wheat

\begin{tabular}{|c|c|c|c|c|c|}
\hline Treatment & $\begin{array}{c}\text { Leaf length } \\
(\mathbf{c m})\end{array}$ & $\begin{array}{c}\text { Leaf width } \\
(\mathbf{c m})\end{array}$ & $\begin{array}{c}\text { Leaf Area } \\
\left(\mathbf{c m}^{\mathbf{2}}\right)\end{array}$ & $\begin{array}{c}\text { Root length } \\
(\mathbf{c m})\end{array}$ & $\begin{array}{c}\text { Shoot length } \\
(\mathbf{c m})\end{array}$ \\
\hline T1 & $27.167 \pm 3.5$ & $0.5 \pm 0.005$ & $10.415 \pm 1.9$ & $13.333 \pm 2.9$ & $55.633 \pm 5.6$ \\
\hline T2 & $25.967 \pm 3.6$ & $0.767 \pm 0.44$ & $15.075 \pm 2.5$ & $08.933 \pm 2.8$ & $59.633 \pm 5.9$ \\
\hline T3 & $19.667 \pm 2.9$ & $0.433 \pm 0.03$ & $6.74 \pm 1.9$ & $14.633 \pm 3.1$ & $58.467 \pm 5.8$ \\
\hline T4 & $26.267 \pm 2.6$ & $0.8 \pm 0.05$ & $15.695 \pm 2.5$ & $10.433 \pm 2.8$ & $54.067 \pm 5.5$ \\
\hline
\end{tabular}

Table 3. Analysis of variance for metals in soil and various parts of wheat

\begin{tabular}{|c|c|c|c|c|}
\hline \multirow{2}{*}{ Source } & \multicolumn{4}{|c|}{ Metal } \\
\cline { 2 - 5 } & Cd & Fe & Zn & Co \\
\hline Soil & $.008^{\mathrm{ns}}$ & $109.06^{\mathrm{ns}}$ & $.007^{\mathrm{ns}}$ & $.234^{\mathrm{ns}}$ \\
\hline Root & $42.29^{\mathrm{ns}}$ & $54.75^{* * *}$ & $.006^{\mathrm{ns}}$ & $.101^{\mathrm{ns}}$ \\
\hline Shoot & $.076^{\mathrm{ns}}$ & $54.71^{* * *}$ & $.011^{\mathrm{ns}}$ & $.092^{\mathrm{ns}}$ \\
\hline Grain & $117.97^{\mathrm{ns}}$ & $44.654^{\mathrm{ns}}$ & $.012^{\mathrm{ns}}$ & \\
\hline
\end{tabular}

***: Significant at 0.001 level, ns: non-significant

Table 4. Mean concentration $(\mathrm{mg} / \mathrm{kg})$ of cadmium, iron, zinc and cobalt in soil root shoot grain of wheat

\begin{tabular}{|c|c|c|c|c|}
\hline Treatment & Soil & Root & Shoot & Grain \\
\hline \multicolumn{5}{|c|}{ Cadmium } \\
\hline T1 & $2.925 \pm 0.2$ & $2.37 \pm 0.2$ & $2.113 \pm 0.2$ & $2.15 \pm 0.3$ \\
\hline T2 & $2.815 \pm 0.2$ & $2.915 \pm 0.2$ & $2.483 \pm 0.3$ & $2.463 \pm 0.2$ \\
\hline T3 & $2.91 \pm 0.3$ & $2.46 \pm 0.2$ & $2.455 \pm 0.2$ & $1.5 \pm 0.3$ \\
\hline T4 & $2.98 \pm 0.2$ & $2.89 \pm 0.2$ & $2.267 \pm 0.3$ & $2.167 \pm 0.2$ \\
\hline \multicolumn{5}{|c|}{ Iron } \\
\hline T1 & $31.723 \pm 3.5$ & $28.767 \pm 3.1$ & $24.217 \pm 2.7$ & $10 \pm 2$ \\
\hline T2 & $38.17 \pm 3.8$ & $35.173 \pm 3.5$ & $30.667 \pm 3.1$ & $18.167 \pm 2.1$ \\
\hline T3 & $37.085 \pm 2.8$ & $32.587 \pm 3.6$ & $28.037 \pm 3.2$ & $17.667 \pm 2.1$ \\
\hline T4 & $41.315 \pm 3.2$ & $38.323 \pm 3$ & $33.813 \pm 3.3$ & $13.25 \pm 2.3$ \\
\hline \multicolumn{5}{|c|}{ Zinc } \\
\hline T1 & $2.2083 \pm 0.07$ & $1.76 \pm 0.02$ & $1.485 \pm 0.07$ & $0.9 \pm 0.04$ \\
\hline T2 & $2.1683 \pm 0.06$ & $1.73 \pm 0.04$ & $1.46 \pm 0.06$ & $0.805 \pm 0.05$ \\
\hline T3 & $2.2317 \pm 0.07$ & $1.773 \pm 0.06$ & $1.567 \pm 0.06$ & $0.893 \pm 0.06$ \\
\hline T4 & $2.285 \pm 0.06$ & $1.84 \pm 0.06$ & $1.593 \pm 0.09$ & $0.957 \pm 0.07$ \\
\hline \multicolumn{5}{|c|}{ Cobalt } \\
\hline T1 & $1.1533 \pm 0.04$ & $0.9517 \pm 0.09$ & $0.863 \pm 0.08$ & $0.535 \pm 0.03$ \\
\hline T2 & $1.1683 \pm 0.06$ & $0.965 \pm 0.08$ & $0.883 \pm 0.09$ & $0.95 \pm 0.04$ \\
\hline T3 & $1.2083 \pm 0.09$ & $0.985 \pm 0.07$ & $0.933 \pm 0.09$ & $0.665 \pm 0.04$ \\
\hline T4 & $1.7333 \pm 0.1$ & $1.333 \pm 0.1$ & $1.4 \pm 0.08$ & $0.67 \pm 0.08$ \\
\hline
\end{tabular}


Table 5. Bioconcentration factor, pollution load index and enrichment factor of wheat

\begin{tabular}{|c|c|c|c|c|}
\hline Treatment & Cd & Fe & Zn & Co \\
\hline \multicolumn{5}{|c|}{ Bioconcentration factor } \\
\hline T1 & 0.8102 & 0.9068 & 0.7969 & 0.8251 \\
\hline T2 & 10.355 & 0.9214 & 0.7978 & 0.8259 \\
\hline T3 & 0.8453 & 0.8787 & 0.7944 & 0.8151 \\
\hline T4 & 0.9697 & 0.9275 & 0.8052 & 0.7690 \\
\hline \multicolumn{5}{|c|}{ Pollution load index } \\
\hline T1 & 273.364 & 0.5575 & 0.0491 & 0.2205 \\
\hline T2 & 263.084 & 0.6708 & 0.0482 & 0.2233 \\
\hline T3 & 271.962 & 0.6517 & 0.0497 & 0.2310 \\
\hline T4 & 278.504 & 0.7260 & 0.0508 & 0.3314 \\
\hline \multicolumn{5}{|c|}{ Enrichment factor } \\
\hline T1 & 54.760 & 0.0421 & 0.1811 & 0.0844 \\
\hline T2 & 65.184 & 0.0636 & 0.1650 & 0.1479 \\
\hline T3 & 38.402 & 0.0637 & 0.1778 & 0.1001 \\
\hline T4 & 54.175 & 0.0428 & 0.1861 & 0.0703 \\
\hline
\end{tabular}

Table 6. Transfer factor for all heavy metals of wheat

\begin{tabular}{|c|c|c|c|c|}
\hline Treatment & Cd & Fe & Zn & Co \\
\hline \multicolumn{5}{|l|}{ Root-Shoot } \\
\hline T1 & 0.8915 & 0.8418 & 0.8437 & 0.9067 \\
\hline T2 & 0.8518 & 0.8718 & 0.8439 & 0.9150 \\
\hline T3 & 0.9979 & 0.8603 & 0.8838 & 0.9472 \\
\hline T4 & 0.7844 & 0.8823 & 0.8657 & 10.502 \\
\hline \multicolumn{5}{|c|}{ Shoot-Grain } \\
\hline T1 & 10.175 & 0.4129 & 0.6060 & 0.61993 \\
\hline T2 & 0.9919 & 0.5923 & 0.5513 & 10.758 \\
\hline T3 & 0.6109 & 0.6301 & 0.5698 & 0.7127 \\
\hline T4 & 0.9558 & 0.3918 & 0.6007 & 0.4785 \\
\hline
\end{tabular}

Table 7. Daily intake of metal and health risk index via intake of wheat

\begin{tabular}{|c|c|c|c|c|}
\hline Treatment & Cd & Fe & Zn & Co \\
\hline \multicolumn{5}{|c|}{ Daily intake of metals } \\
\hline T1 & 0.0123 & 0.0575 & 0.0051 & 0.4458 \\
\hline T2 & 0.0141 & 0.1044 & 0.0046 & 0.7916 \\
\hline T3 & 0.0086 & 0.1015 & 0.0051 & 0.5541 \\
\hline T4 & 0.0124 & 0.0761 & 0.0055 & 0.5583 \\
\hline \multicolumn{5}{|c|}{ Health risk index } \\
\hline T1 & 847.838 & 57.412 & 0.0139 & 103.682 \\
\hline T2 & 575.863 & 10.446 & 0.0125 & 184.108 \\
\hline T3 & 503.125 & 101.585 & 0.0138 & 128.876 \\
\hline T4 & 503.7 & 76.188 & 0.0148 & 129.844 \\
\hline
\end{tabular}

Table 8. Metal correlation between different levels of wheat

\begin{tabular}{|c|c|c|c|}
\hline Metal & Soil-Root & Root-Shoot & Shoot-Grain \\
\hline $\mathrm{Cd}$ & 0.255 & 0.598 & 0.554 \\
\hline $\mathrm{Fe}$ & 0.356 & $1.000 * *$ & 0.636 \\
\hline $\mathrm{Zn}$ & $0.985^{*}$ & 0.884 & 0.817 \\
\hline $\mathrm{Co}$ & $1.000^{* *}$ & $0.999^{* *}$ & -0.125 \\
\hline
\end{tabular}

$*, * *$ : Correlation is significant at the 0.05 and 0.01 level 
The mean value of $\mathrm{Cd}$ was higher compared to value $(0.46 \mathrm{mg} / \mathrm{kg})$ given by $\mathrm{Yu}$ et al . [19]. Cadmium content $(0.34 \mathrm{mg} / \mathrm{kg})$ given by Ekmekyapar et al. [20] was lower than current value. In the body, excess $\mathrm{Cd}$ interrupts bone metabolism, kidneys, deforms endocrine system and reproductive tract. It is an accumulative carcinogen and toxicant. Due to long-term exposure to $\mathrm{Cd}$ in the kidneys, numerous morphophysiological changes occur. Renal toxicity decreases by intake of $\mathrm{Zn}$ that is caused by intake of $\mathrm{Cd}$. In soil the concentration of $\mathrm{Fe}$ ranged from 31.7 to $41.3 \mathrm{mg} / \mathrm{kg}$. In the present study, $\mathrm{Fe}$ content was lower compared to value $(270 \mathrm{mg} / \mathrm{kg})$ given by Hassan et al. [16]. The Fe content was lower in another study carried out by Mojiri and Aziz [21]. The Fe concentration of $6205 \mathrm{mg} / \mathrm{kg}$ given by Ekmekyapar et al. [20] was higher than the current value. The value of $\mathrm{Fe}(21 \mathrm{mg} / \mathrm{kg})$ observed by Balkhair and Ashraf [22] was approximately similar to present value. The $\mathrm{Fe}$ content was similar to present value given by Feizi [23] that was $32 \mathrm{mg} / \mathrm{kg}$. Zn content varied from 2.160 to $2.280 \mathrm{mg} / \mathrm{kg}$. The value of $\mathrm{Zn}$ in current study was higher than estimation of $7.31 \mathrm{mg} / \mathrm{kg}$ given by Rattan et al. [17]. The lower value of $\mathrm{Zn}$ was observed in the present investigation as compared to value $129.08 \mathrm{mg} / \mathrm{kg}$ given by Yu et al. [19]. Lower $\mathrm{Zn}$ content in current work was detected as compared to 59.1 $\mathrm{mg} / \mathrm{kg}$ given by Aydin et al. [24]. The zinc concentration (35 $\mathrm{mg} / \mathrm{kg})$ given by Ekmekyapar et al. [20] was higher than current value. The value of $\mathrm{Zn}$ in a study carried out by Salakinkop and Hushnal [25] was nearly similar to present value. The Co concentration in soil ranged from 1.150 to $1.730 \mathrm{mg} / \mathrm{kg}$. The result of present research showed lower Cd content as compared to the values of Shad et al. [26] that was 5.33 $\mathrm{mg} / \mathrm{kg}$. The value of Co $(1.73 \mathrm{mg} / \mathrm{kg})$ given by Ahmad et al. [27] was similar to current value. The values of Co given by Bibi et al. [28] $(17.63 \mathrm{mg} / \mathrm{kg})$ and Chiroma et al. [29] $(14.4 \mathrm{mg} / \mathrm{kg})$ were higher than current study. The cobalt concentration was lower in present study than estimated value of $18.9 \mathrm{mg} / \mathrm{kg}$ given by Page et al. [30].

The Cd content ranged from 1.50 to 2.46 $\mathrm{mg} / \mathrm{kg}$ in grains of wheat. In current study, the value of $\mathrm{Cd}$ was higher as compared to value $0.062 \mathrm{mg} / \mathrm{kg}$ given by $\mathrm{Yu}$ et al. [19]. Concentration of $\mathrm{Cd}$ was higher in current to value $0.10 \mathrm{mg} / \mathrm{kg}$ estimated by Stefanovic et al. [31]. Cadmium affect negatively if accumulates in the body of human and effects several organs: lung, liver, bones, kidney, central nervous system, placenta and brain [32]. The other damages that have been detected include development toxicity, hematological effects hepatic and reproductive disorders [33].

The value of $\mathrm{Cd}(0.29 \mathrm{mg} / \mathrm{kg})$ given by Singh et al. [34] was lower compared to present value. The value of $\mathrm{Cd}$ in present study was higher than $0.06 \mathrm{mg} / \mathrm{kg}$ given by Zeng et al. [35]. The permissible value of $\mathrm{Cd}$ is $0.20 \mathrm{mg} / \mathrm{kg}$ [36]. Cd is not useful for human and plant health. $\mathrm{Cd}$ is willingly taken up by plants due to its natural presence in soils. Use of commercial sludge as fertilizer maybe the possible source of Cd toxicity in plants.

The concentration of $\mathrm{Fe}$ in grains of wheat in present study ranged from 10 to 18.16 $\mathrm{mg} / \mathrm{kg}$. Iron concentration given by Ekmekyapar et al. [20] (151 mg/kg) was higher in comparison to present value. The value of $\mathrm{Fe}(404 \mathrm{mg} / \mathrm{kg})$ was higher in another study carried out by Rattan et al. [17] in contrast to present study. The Fe content was lower in current study to value of $35.63 \mathrm{mg} / \mathrm{kg}$ given by Stefanovic et al. [31].

Concentration of $\mathrm{Zn}$ was lower in current study as given by Stefanovic et al. [31]. The $\mathrm{Zn}$ content was higher than the present value given by Feizi [23] that was 26 $\mathrm{mg} / \mathrm{kg}$. The permissible value of $\mathrm{Zn}$ given by Weigert [36] was $99.40 \mathrm{mg} / \mathrm{kg}$. The range of $\mathrm{Zn}$ was useful for health of humans in current study. 
In the present work, the Co concentration in grains of wheat variety ranges from 0.50 to $0.95 \mathrm{mg} / \mathrm{kg}$. The value of Co was higher to present value $5.340 \mathrm{mg} / \mathrm{kg}$ given by Samera et al. [37]. The Co concentration was lower in current study to value $81.1 \mathrm{mg} / \mathrm{kg}$ demonstrated by Page et al. [30]. The value was similar to value reported by Shad et al. [26] that was $0.15 \mathrm{mg} / \mathrm{kg}$ in grains of wheat. Most relatively high Co content present in leafy plants, like cabbage, lettuce and spinach while lower in cereals and grasses. Co was also important for many legumes because it was an essential micronutrient for some nitrogen fixing bacteria, such as Rhizobium.

In current investigation $\mathrm{BCF}$ for all findings were higher than the findings of Puschenreiter et al. [38]. In recent study TF for $\mathrm{Cd}$ was higher as compared to those values as reported by Ullah et al. [39]. The value of $\mathrm{Cd}$ was high while value for $\mathrm{Zn}$ was lower than values reported by Balkhair and Ashraf [22]. Wang et al. [40] reported low values for $\mathrm{Cd}$ and $\mathrm{Zn}$.

The pollution load index values of $\mathrm{Zn}$ and Cd were lower from the values 2.1 and 84 respectively as demonstrated by Khan et al. [41]. Pollution load index had lower values of $\mathrm{Fe}$ and $\mathrm{Zn}$ in current work as compared to values of 0.74 and 0.07 respectively given by Khan et al. [42]. The level of pollution or factor of contamination was lowest for $\mathrm{Zn}$ and highest for $\mathrm{Cd}$ in all treatments.

The load of pollution increases day by day due to agricultural runoff and human activities. For all metals, the load of pollution in current study was lower compared to the results of Bibi et al. [28]. If pollution load index value was higher than 1 the heavy metals were injurious to health. To minimize the extent of pollution severity proper monitoring of soil is necessary.

The population will be at greater risk if DIM was greater than 1 [14]. In current investigation value of DIM was less than 1 . The value of DIM was higher given by Khan et al. [42] than the values of present study. The estimated average DIM for children up to 6 years was 0.1315 and $0.0437 \mathrm{~kg} /$ person/day) correspondingly and average body weights were estimated to be 61.6 and $18.6 \mathrm{~kg}$ respectively [43].

Health risk index in present findings were greater than 1. Singh et al. [34] also recorded high value of HRI for $\mathrm{Cd}$ as compared to current findings. Health risk index for Fe was similar to those given by Cui et al. [12]. Consumption of food crop as safe if value OF HRI $<1$ (Khan et al. 2008)

When enrichment value is high $(>1)$ it indicates higher availability and distribution of metals. The enrichment factor value given by Likuku et al. [44] was higher while $\mathrm{Zn} 1.25$ was higher as compared to present value. The values of EF in our work were similar to the findings of Fytianos et al. [45].

In current findings, $\mathrm{Zn}, \mathrm{Cd}$ and $\mathrm{Fe}$ exhibited positive and non-significant while Co showed negative and non-significant correlation. Positive and non-significant correlation were also observed by Khan et al. [46] for metal $\mathrm{Zn}$.

\section{Conclusion}

It is concluded that the municipal soil waste contains surplus amount of heavy metals and when this was used in agricultural land it contaminates the soil and crop grown there and pose various clinical problems to consumers. In current investigation, values of $\mathrm{Fe}, \mathrm{Zn}$ and $\mathrm{Co}$ in soil and grains were fall within the acceptable range given by FAO/WHO but the concentration of $\mathrm{Cd}$ exceeded the permissible limit. Cadmium could be considered potentially dangerous as it exceeded WHO limits and its HRI value was $>1$. This could be due to the application of municipal solid waste. So therefore, we must have to pass this solid waste through proper treatment to decrease its harmful effect.

\section{Authors' contributions}

Conceived and designed the experiments: ZI Khan \& K Ahmad, Performed the experiments: IF Malik, M Ghazzal, $\mathrm{H}$ Bashir, M Munir \& A Ashfaq, Analyzed the 
data: K wajid, M Sana \& K Nawaz, Contributed reagents/materials/analysis tools: T Abbas, M Nadeem \&N Mehmood, Wrote the paper: Z Fatima, H Muqaddas, M Shahzadi \& S Ullah.

\section{References}

1. Tripathi A \& Prasad AR (2010). Agricultural Development in India since Independence: A Study on Progress, Performance, and Determinants. $J$ Emerg Knowled Emerg Market 1(1): 62-92.

2. Sarwar MH, Sarwar MF, Sarwar M, Qadri NA \& Moghal S (2013). The importance of cereals (Poaceae: Gramineae) nutrition in human health: A review. J Cereals Oilseeds 4(3): 3235.

3. Kukier U, Peters CA, Chaney RL \& Angle JS (2004). The effect of $\mathrm{pH}$ on metal accumulation in two Alyssum species. J Environ Qual 33: 20902102.

4. Basta NT, Ryan JA \& Chaney RL (2005). Trace elements chemistry in residual-treated soils: key concepts and metal bioavailability. J Environ Qual 34: 49-63.

5. Cui Y, Zhu YG, Zhai R, Huang Y, Qiu Y \& Liang J (2005). Exposure to metal mixtures and human health impacts in a contaminated area in Nanning, China. Environ Int 31: 784-790.

6. Al-Suba MM, Haddad M, Mizyed N \& Mizyed I (2003). Impacts of irrigation water containing heavy metals on soil and groundwater-A simulation study. Water Air Soil Pollut 146: 141-152.

7. Doe ED, Awua AK, Gyamfi OK \& Bentil NO (2013. Levels of selected heavy metals in wheat flour on the Ghanian market: A determination by atomic absorption spectrometry. American J Appl Chem 1(2): 17-21.

8. Ozdemir C \& Dursun S (2004). Trihalomethane determination and removals from the main discharge channel of Konya City
(Turkey). Environ Technol 25(9): 1091-1096.

9. Ahmad K, Nawaz K, Khan ZI, Nadeem M \& Wajid K et al. (2018). Effect of diverse regimes of irrigation on metals accumulation in wheat crop: An assessment-dire need of the day. Fresen Environ Bull 27(2): 846-855.

10. Khan ZI, Ugulu I, Umar S, Ahmad K, Mehmood N, Ashfaq A, Bashir H \& Sohail M (2018). Potential toxic metal accumulation in soil, forage and blood plasma of buffaloes sampled from Jhang, Pakistan. Bull Environ Contam Toxicol 101(2): 235-242.

11. Steel RGD \& Torrie JH (1980). Principles and procedures of statistics. A Biometrical Approach, 2. McGrawHill, New York.

12. Cui YG, Zhu YG, Zhai RH, Chen DY, Huang YZ, Qui Y \& Liang JZ (2004). Transfer of metals from near a smelter in Nanning, China. Environ Int 30: 785-791.

13. Liu WH, Zhao JZ, Ouyang ZY, Soderlund L \& Liu GH (2005). Impacts of sewage irrigation on heavy metals distribution and contamination in Beijing, China. Environ Int 31: 805812.

14. Sajjad K, Farooq R, Shahbaz S, Khan MA \& Sadique M (2009). Health risk assessment of heavy metals for population via consumption of vegetables. World Appl Sci J 6: 16021606.

15. Al-Hwaiti M, Al-Khashman O, AlKhateeb L \& Freig F (2014). Radiological hazard assessment for building materials incorporating phosphogypsum made using Eshidiya mine rock in Jordan. Environ Earth Sci 71(5): 2257-2266.

16. Hassan NU, Mahmood Q, Waseem A, Irshad M \& Pervez A (2013). Assessment of heavy metals in wheat plants irrigated with contaminated wastewater. Polish $J$ Environ Stud 22(1): 155-123. 
17. Rattan RK, Datta SP, Chhonkar PK, Suribabu K \& Singh AK (2005). Longterm impact of irrigation with sewage effluents on heavy metal content in soils, crops and groundwater-a case study. Agri Ecosys Environ 109(3-4): 310-322.

18. Iqbal MZ \& Mehmood T (1991). Influence of cadmium toxicity on generation and growth of some common trees. Pak J Sci Indust Res 34: 140-142.

19. Yu X, Wang Z, Lynn A, Cai J, Huangfu Y, Geng, Y, Tang T \& Zeng $X$ (2016). Heavy Metals in wheat grown in sewage irrigation: a distribution and prediction model. Polish J Environ Stud 25(1): 413-418.

20. Ekmekyapar F, Sabudak T \& Seren G (2012). Assessment of heavy metal contamination in soil and wheat (Triticum aestivum L.) plant around the Corlu-Cerkezkoy Highway in Thrace Region Global. Nest J 14(4): 496-504.

21. Mojiri \& Aziz HA (2011). Effects of municipal wastewater on accumulation of heavy metals in soil and wheat (Triticum aestivum L.) with two irrigation methods. Romanian Agric Res 28: 217-222.

22. Balkhair KS \& Ashraf MA (2016). Field accumulation risks of heavy metals in soil and vegetable crop irrigated with sewage water in western region of Saudi Arabia. Saudi J Biol Sci 23: S23-S44.

23. Feizi M (2001). Effect of treated wastewater on accumulation of heavy metals in plants and soil. ICID International workshop on wastewater Reuse Management.

24. Aydin ME, Aydin S, Beduk F, Tor A, Tekinay A, Kolb M \& Bahadir M (2015). Effects of long term irrigation with untreated municipal waste on soil properties and crop quality. Environ Sci Poll Res 22: 19203-19212.

25. Salakinkop SR \& Hunshal CS (2014). Domestic sewage irrigation on dynamics of nutrients and heavy metals in soil and wheat (Triticum aestivum L.) production. Int $J$ Recycl Organic Waste Agric 3: 64.

26. Shad HA, Khan ZI, Ahmad K, Rizwan Y \& Tahir HM (2014). Human health hazards caused by heavy metals accumulation in wheat variety "Sehar2006" irrigated with domestic sewage water. Biologia (Pakistan) 60(1): 99102.

27. Ahmad K, Khan ZI, Ashfaq A, Ashraf M \& Yasmin S (2014). Assessment of heavy metal and metalloid levels in spinach (Spinacia oleracea L.) grown in wastewater irrigated agricultural soil of Sargodha, Pakistan. Pak J Bot 46(5): 1805-1810.

28. Bibi Z, Khan ZI, Ahmad K, Ashraf M, Hussain A \& Akrram NA (2014). Vegetables as a Potential Source of Metals and Metalloids for Human Nutrition: A case study of Momordica charantia Grown in soil irrigated with Domestic Sewage Water in Sargodha, Pakistan. Pak J Zool 46(3):633-641.

29. Chiroma TM, Ebewele RO \& Hymore FK (2014). Comparative assessment of heavy metal levels in soil, vegetables and urban grey waste water used for irrigation in Yola and Kano. Int Refereed J Eng Sci 3: 01-09.

30. Page V, Bayon RCL \& Feller U (2006). Partitioning of zinc, cadmium, manganese and cobalt in wheat (Triticum aestivum) and lupin (Lupinusalbus) and further release into the soil. Environ Experiment Bot 58: 269-278.

31. Stefanović VŽ, Filipović NK \& Jovanović BM (2008). Undesirable metals content in wheat of different wheat varieties. Acta Periodica Technol (39), 69-76.

32. Castro-Gonzalez MI \& MendezArmenta M (2008). Heavy metals: Implications associated to fish consumption. Environ Toxicol Pharmacol 26: 263-271.

33. Apostoli, P and S. Catalani. 2011. Metal ions affecting reproduction and 
development. Metal Ions in Life Sci 8: 263-303.

34. Singh A, Sharma RK, Agrawal M \& Marshall FM (2010). Health risk assessment of heavy metals via dietary intake of food stuffs from the waste water irrigated site of a dry tropical area of India. Food Chemical Toxicol 48: 611-619.

35. Zeng X, Wang Z, Wang J, Guo J, Chen $X$ \& Zhuang J (2015). Health risk assessment of heavy metals via dietary intake of wheat grown in Tianjin sewage irrigation area. Ecotoxicol 24: 2115-2124.

36. Weigert $P$ (1991). Metals and their compounds in the environment occurance, analysis and biological reverence. In: Merian, (Ed.), pp 458468.

37. Samera B, Devi P, Gogoi N \& devi YM (2014). Effects of cobalt induced stress on Triticum aestivum L. Crop. Asian J Agric Biol 2(2): 137-147.

38. Puschenreiter M, Horak O, Friesl W \& Hartl W (2005). Low-cost agricultural measures to reduce heavy metal transfer into the food chain-a review. Plant Soil Environ 51(1): 1-11.

39. Ullah H, Khan I \& Ullah I (2012). Impact of sewage contaminated water on soil, vegetables, and underground water of peri-urban Peshawar, Pakistan. Environ Monit Assess 184(10): 6411-6421.

40. Wang Z, Zeng X, Geng M, Chen C, Cai J, Yu X, Hou Y \& Zhang H (2015). Health risks of heavy metals uptake by crops grown in a sewage irrigation area in China. Polish J Environ Stud 24(3): 1379-1386.
41. Khan S, Cao Q, Zheng YM, Huang YZ \& Zhu YG (2008). Health risks of heavy metals in contaminated soils and food crops irrigated with waste water in Beijing, China. Environ Pollut 152(3): 686-692.

42. Khan ZI, Ahmad K, Ashraf M, Yasmeen S, Ashfaq A \& Sher M (2016). Metal accumulation in a potential winter vegetable mustard (Brassica campestris L.) irrigated with different types of waters in Punjab, Pakistan. Pak J Bot 48(2): 535-541.

43. Wang C, Zhang SH, Wang PF, Hou J, Zhang WJ, Li W \& Lin ZP (2009). The effect of excess Zinc on mineral nutrition and anti-oxidative response in rapeseed seedling. Chemosphere 75: 1468-1476.

44. Likuku AS, Mmolawa KB \& Gaboultloeloe GK (2013). Assessment of heavy metal enrichment and degree of contamination around the coppernickel mine in the Selebi Phikwe region, Eastern Botswana. Environ Ecol Res 1(2): 32-40.

45. Fytianos K, Katsianis G, Riantafyllou P \& Zachariadis G (2001) Accumulation of heavy metals in vegetables grown in an industrial area in relation to soil. Bull Env Contam Tox 67: 423-430.

46. Khan ZI, Ahmad K, Ashraf M, Akram NA, Rizwan Y, Shaheen M \& Arshad F (2013). Assessment of potential toxicological risk for public health of heavy metals in wheat crop irrigated with waste water: a case study in Sargodha, Pakistan. Asian J Chem 25(17): 9704-9706. 